\title{
The Emerging Mobile Media Market: Exploring the Potential of Tablets for Media Content Consumption
}

\section{Sylvia Chan-OImsted ${ }^{1}$ Ronen Shay ${ }^{2}$}

Recibido: 2014-06-25

Enviado a pares: 2014-06-25
Aprobado por pares: 2014-09-10

Aceptado: 2014-10-22

DOI: $10.5294 /$ pacla.2014.17.4.10

\section{Para citar este artículo / To reference this article / Para citar este artigo}

Chan-Olmsted S., Shay, R. Diciembre de 2014. The Emerging Mobile Media Market: Exploring the Potential of Tablets for Media Content Consumption. Palabra Clave 17(4), 1213-1240. DOI: 10.5294/pacla.2014.17.4.10

\section{Abstract}

In adopting the qualitative research method of semi-structured self-completion diaries, this study explores how young adult consumers utilize tablets to consume media content traditionally available through television, radio, newspaper, and magazine platforms, perceptions of tablets as a media content platform in terms of benefits/needs met, accessibility, compatibility with existing media, usefulness, ease of use, and fun, how a tablet substitutes and/or complements traditional media usage, and the adoption factors that are important for users to adopt the tablet platform for mobile media consumption. The results show all the participants had positive video viewing experiences, supporting the claim that tablets are well designed for the consumption of video entertainment content. From the perspective of

\footnotetext{
University of Florida, Estados Unidos. chanolmsted@jou.ufl.edu

University of Florida, Estados Unidos.rshay@ufl.edu
} 
music/audio content, the participants seemed to indicate their needs might be better fulfilled by other smaller portable devices. On the other hand, the positive reading experiences described by the participants further expand the substitutive nature of the tablet for text/image content consumption. The findings presented here generally support the notions presented in the TTF framework, as the participants consistently evaluated their satisfaction of the tablet as a media platform dependent on how the device best delivered their media content.

\section{Keywords}

Mobile media, consumption, uses and gratifications, audiences, media market. (Source: Unesco Thesaurus). 


\section{El mercado emergente de los medios de comunicación móvil: exploración del potencial de las tabletas para el consumo de los contenidos multimedia}

\section{Resumen}

$\mathrm{Al}$ adoptar el método de investigación cualitativa de los diarios semiestructurados que el usuario completa por sí mismo, este estudio explora cómo los jóvenes adultos consumidores utilizan las tabletas para consumir los contenidos de los medios tradicionalmente disponible a través de plataformas de televisión, radio, periódicos, revistas, las percepciones de las tabletas como una plataforma de contenidos de los medios en términos de beneficios / necesidades cubiertas, la accesibilidad, la compatibilidad con los medios existentes, la utilidad, facilidad de uso, y la diversión, de cómo una tableta sustituye o complementa el uso de los medios tradicionales, así como los factores de adopción que son importantes para que los usuarios puedan adoptar la plataforma de la tableta para el consumo de los medios móviles. Los resultados muestran que todos los participantes tuvieron experiencias de visión de video positivas, lo que respalda la afirmación de que las tabletas están bien diseñadas para el consumo de contenidos de entretenimiento en formato de vídeo. Desde la perspectiva de contenido de música/audio, los participantes parecían indicar que sus necesidades las pueden cubrir mejor otros dispositivos portátiles más pequeños. Por otra parte, las experiencias positivas de lectura descritas por los participantes expanden aún más la naturaleza sustitutiva de la tableta para el consumo de contenidos de texto/imagen. Los resultados presentados aquí apoyan en general las nociones presentadas en el marco de TTF, a medida que los participantes evaluaron sistemáticamente su satisfacción de la tableta como una plataforma de medios que depende de cómo el dispositivo entrega mejor sus contenidos de medios.

\section{Palabras clave}

Medios de comunicación móviles, consumo, usos y gratificaciones, audiencias, mercado de medios. (Fuente: Tesauro de la Unesco). 


\section{0 mercado emergente dos meios de comunicação móvel: explorando 0 potencial dos tablets para o consumo dos conteúdos multimídia}

\section{Resumo}

Ao adotar o método de pesquisa qualitativa dos diários semiestruturados que o usuário completa por si mesmo, este estudo explora como os jovens adultos consumidores utilizam os tablets para consumir os conteúdos dos meios tradicionalmente disponíveis por meio de plataformas de televisão, rádio, jornais, revistas. Além disso, explora as percepções dos tablets como plataforma de conteúdos dos meios em termos de benefícios/necessidades cobertas, a acessibilidade, a compatibilidade com os meios existentes, a utilidade, a facilidade de uso e a diversão, de como um tablet substitui e/ou complementa o uso dos meios tradicionais, bem como os fatores de adoção que são importantes para que os usuários possam adotar a plataforma do tablet para o consumo dos meios móveis. Os resultados mostram que todos os participantes tiveram experiências de visão de vídeo positivas, o que sustenta a afirmação de que os tablets estão bem desenhados para o consumo de conteúdos de entretenimento em formato de vídeo. Sobre o conteúdo de música/áudio, os participantes pareciam indicar que suas necessidades podem ser mais bem cobertas por outros dispositivos portáteis menores. Por outro lado, as experiências positivas de leitura descritas pelos participantes expandem ainda mais a natureza substitutiva do tablet para o consumo de conteúdos de texto/imagem. Os resultados apresentados aqui apoiam em geral as noções apresentadas no marco de TTF, à medida que os participantes avaliaram sistematicamente sua satisfação com o tablet como uma plataforma de meios que depende de como o dispositivo entregava melhor seus conteúdos de meios.

\section{Palavras-chave}

Meios de comunicação móveis, consumo, usos e gratificações, audiências, mercado de meios. (Fonte: Tesauro da Unesco). 
In its 2013Mobile Consumer Report, Nielsen called mobile platforms "the Next Media Powerhouse" and declared that the ownership of mobile devices has reached a critical mass, thus playing an increasingly important role in the daily lives of media consumers around the world (Nielsen, 2013). While not yet a substitute for traditional media such as television, mobile devices are providing consumers with more opportunities to engage with media content ubiquitously throughout their daily activities (Nielsen, 2013; Smith \& Boyles, 2012). Pew Research Center coined the term "the connected viewer" in reference to half of US adult cell phone owners having used their phones for engagement, diversion, or interaction with others while watching television (Smith \& Boyles, 2012). Among the various mobile platforms, the pace of consumer adoption of tablets is accelerating. The global tablet market grew a staggering $75 \%$ in 2012 , reaching 52.5 million units in its fourth quarter (Li, 2013). Apple's iPad leads the charge with almost $50 \%$ of the tablet market, followed by Samsung's Android and Windows tablets with $15 \%$ ( $\mathrm{Li}, 2013)$. By the fall of 2012, about a quarter of the adult population in the United States owned tablet-type devices (Rainie, 2012).

Unlike its smartphone counterpart, tablet adoption seems to be less age/youth dependent. For example, smartphone penetration rates for adults ages $18-24$ and $35-44$ are 58\% and 47\%, respectively; tablet adoption rates for the same two groups are 19\% and 18\% (Rainie, 2012). Interestingly enough, older adults are heavier users of tablets and watch more videos via these devices than their younger counterparts (Adobe, 2012). In addition, most tablet usage occurs at home instead of in-transit or at work (Adobe, 2012). These adoption and usage patterns point to the potential for tablets to achieve cross-demographic viability as a ubiquitous media consumption platform for both in home and out-of-home use. As the tablet market continues to lower its selling prices and offer a wide range of new products, it is likely this platform will become a major medium from which consumers choose to access entertainment and information content.

As media industries contemplate ways to integrate this emerging mobile platform into their delivery portfolio, it is essential to first understand how consumers perceive and use tablets for media content consumption. 
Aside from portability, tablets differ significantly from traditional mass media when used for media consumption. They are personal devices, but also have the potential to be shared with family members. Tablets afford the capacity to read and manipulate texts and graphics; watch, pause, and replay videos; listen to music and radio stations; surf the Internet; use an extensive array of apps; and multitask within the device, as well as with other media. Therefore, our past assumptions in how consumers watch video, read magazines/newspapers, use computers, or listen to music might no longer hold true in this context. Nevertheless, most tablet-related studies thus far have focused on the "productivity" or "educational" perspective of the adoption. Accordingly, this study looks to address tablets from the standpoint of an emerging media device intended to be used to consume content traditionally available on other platforms such as video, audio, news, and social media. When Apple launched the iPad, it was quick to remind critics that it is the users who define the dominant uses of a new product (Palenchar, 2010). Accordingly, this study adopts a qualitative field-research methodology to allow the subjects to use tablets in their natural surroundings, and to reflect on their feelings and usage experiences via a video media diary. As a result of the emerging nature of tablets as media consumption devices, such an approach is likely to capture in-depth and accurate consumer perceptions and usage recalls.

\section{The Rise of Mobile Mass Media: Tablets and Their Users}

Tablet adoption rates experienced unprecedented growth in 2012, with ownership of the platform growing twice as fast as smartphone adoption (Singh, 2012). Consumers even indicated they prefer a tablet over a personal computer (PC) as a gift; this as PC sales continue to decline (Ballve, 2012). What do we know about tablet users? According to Adobe's (2012) national mobile consumer survey, adults ages 30-49 and 50-64 are heavier users of tablets than their younger counterparts ages 18-29. This heavier usage pattern for older users carries over to video consumption, as the same study demonstrated that users ages 50-64 are the demographic group most likely to watch videos via tablets. All three age groups tend to use tablets at home instead of in-transit or at work (Adobe, 2012). This particular ob- 
servation has important implications, as it means the tablet can be used as a valid alternative for mass media content consumption, potentially challenging more traditional at-home peripherals like television.

Gaming is an important tablet activity for younger adults, as over $25 \%$ of both the 18-29 and 30-49 age groups said they use tablets to play games (Adobe, 2012). About 15\% of all three demographics used tablets to read books, but only $5 \%$ of them used tablets to read news or magazines. Although iPads are the most popular among the two younger age groups $(27 \%$ and $31 \%)$, Kindle Fire is preferred by the older group (22\%) (Adobe, 2012). Ultimately, it was also found that, for consumers who own a smartphone and a tablet, their primary device continues to be the smartphone (88\%) (Adobe, 2012).

Further findings from Adobe's (2012) study demonstrate that tablets appear to be considered family property, as over half the owners share their devices with other family members. Facebook is the dominant social media accessed via mobile device ( $85 \%$ of participants), followed by Twitter ( $35 \%$ of participants); slightly more women own tablets ( $27 \%$ women : $24 \%$ men). Finally, adults ages $30-49$ are most likely to own a tablet $(31 \%)$, followed by adults ages 50-64 (27\%), and those ages 18-29 (25\%) (Adobe, 2012). A separate study conducted by the Pew Research Center analyzed tablet ownership in terms of socio-economic status and found that $47 \%$ of those living in households earning $\$ 75,000$ or more now own a tablet (Rainie, 2012).

\section{Theoretical Framework}

This study adopts a modified task-technology fit (TTF) model as the basis for its theoretical framework. The decision to modify the traditional TTF measure stems from a desire to expand the model's intended focus beyond productivity to include entertainment and information performance. Justification for the themes selected for examination is further drawn from the technology acceptance model (TAM), the uses and gratifications approach (U\&G), playability/fun usage research, and substitutive technologies research. 


\section{Task-Technology Fit}

The original TTF model is concerned with individual productivity in terms of job performance (Goodhue \& Thompson, 1995), and has seen much success in assessing the effectiveness of new technological devices as a productivity tool for students (McGill \& Hobbs, 2008; McGill, Klobas \& Renzi, 2011). In general, TTF argues that technological devices are more likely to have a positive impact on individual job performance if they fit the usage capabilities of the task that must be completed (Goodhue \& Thompson, 1995). In other words, the match between the task parameters and technology characteristics would affect the performance of the task and future utilization of the technology. The implication of such an argument from a user's perspective is that users must match the right device to the right task for satisfactory outcome and continuous use. Various TTF studies have attempted to assess the degree of task-technology fit from the perspective of user-using factors like information quality/accuracy, accessibility, compatibility, reliability, needs met, and preference among alternative technologies (Goodhue \& Thompson, 1995; Lee, Euiho \& Park, 2012; Staples \& Seddon, 2004; Zigurs \& Buckland, 1998). In the context of this study, the performance goal is not productivity, but effective consumption of entertainment and/or information content; the task is media content usage/consumption and the technology is tablet devices. Accordingly, with the assumption that the perceived fit between the technology and the task would impact the technology's outcome and use, this study will explore how the factors of accessibility, compatibility, needs met, and preference among media platforms influence the perception of use of tablets for media content consumption.

\section{Technology Acceptance Model}

To augment the TTF framework for assessing tablet adoption and its related media consumption, the technology acceptance model (TAM) has been incorporated into the study. The TAM argues that perceived usefulness and perceived ease of use effectively predict a user's intention to use a technological device or information system (Davis, 1989). Perceived usefulness is a measure of the extent to which a user believes the technology in question will help him/her to perform their job (Davis, 1989). Perceived ease 
of use is a measure of the effort required in using the technology (Davis, 1989). Should a user come across a technology he/she believes will be of assistance, there will initially be a high perceived usefulness and intention to use; however, if the actual system proves to be too difficult to use, then perceived ease of use will be low and the effort required to operate the technology will outweigh any productivity benefits gained. As both ease of use and perceived usefulness have a strong historical precedence of accurately predicting technology acceptance among college students (Moran, 2006), early adopters (Suki, 2011), and smartphone purchasing decisions (Lee, Euiho, \& Park, 2012), their application to this study's theoretical framework as potential factors that contribute to successful tablet adoption is reasonable and well supported.

\section{Uses and Gratifications Approach}

Tablet devices, as a result of hardware and software convergence, possess a multitude of functionalities that can be investigated through the uses and gratifications (U\&G) approach to technology adoption. Early $U \& G$ research focused on Schramm's (1954) fraction of selection, a similar approach to TAM; it explains that an individual's media consumption decisions are based on the expectation of reward (perceived usefulness) relative to the effort required to extract those rewards (perceived ease of use) (Schramm, 1954). Contemporary U\&G deals with interactivity, demassification and asynchroneity (Ruggiero, 2000). The interactivity provided by tablets allows users to have greater control over their communication processes, strengthening the concept of an active user (Katz, Blumler \& Gurevitch, 1973; Ruggiero, 2000; William, Rice \& Rogers 1988). Tablets contribute to demassification as a result of their ability to offer a wide range of selectivity and customization capabilities, allowing users to tailor the media and communication features of the device to meet their needs. Finally. advancements in storage and compression technologies support the asynchroneitic nature of photos, videos, and communications created/mediated on a tablet (Ruggiero, 2000). Various empirical studies have successfully applied the contemporary U\&G framework to the study of tablet adoption (Batsell, 2012; Murray, 2011). Accordingly, the intended uses and overall gratifications of tablet usage for media consumption will be explored. 


\section{The Fun Factor}

One aspect that could be classified as a benefit, but has been historically treated as its own factor by researchers in previous studies (Kim \& Sim, 2012; Lee, Euiho \& Park, 2012; Ozok, Benson, Chakraborty \& Norcio, 2008), is the amount of fun the engagement with a tablet has provided users. Often measured using the term playfulness, playability or the broader designation of fun factor, multiple studies have identified a latent attitudinal outcome where users feel intrinsic enjoyment, interest, fun, or curiosity as a result of using a tablet (Lee, Euiho \& Park, 2012). This fun factor is not an arbitrary designation by researchers, as participant accounts from studies conducted on early tablet PCs identified "fun" as a key motivator when selecting a device for email, chatting, web surfing, and casual scribbling (Ozok, et al., 2008). A comparative study between tablet and PC usage acknowledges that tablets offer users a latent fun factor that can be viewed as a positive motivator for acceptance of the medium (Ozok, et al., 2008). Kim and Sim's (2012) qualitative study in which interviews and surveys were conducted with users of tablets to assess ongoing satisfaction identified "playability" as a unique attribute that has an important influence on consumers' acceptance, use, and behavior towards an IT device (Kim \& Sim, 2012). Further support can be drawn from Igbaria and Liravi's (1995) study on the self-efficacy of computer usage (Igbaria \& Liravi, 1995). The sheer volume of studies that identify fun as a major motivator for tablet adoption supported the decision to include it as another theme to explore in this study.

\section{Substitutability and Complementarity of Tablets}

As mentioned earlier in the TTF discussion, the degree of task-technology fit can be assessed from the perspective of user preferences for a certain technology among the alternatives for the task at hand (i. e., preferences for substitutable technologies for the task or focus). A substitutive device is one that provides the same functionality as an existing technology and, therefore, does not contribute to the continued use of existing devices, but effectively replaces them. On the other hand, a complementary device is one that provides additional functionality when used in combination with another technology (Ha \& Ganahl, 2004). Because tablet devices deliver 
an array of functionality that can be found traditionally on multiple media platforms, how consumers perceive the device as a substitute or a complement to their existing media portfolio should play a role in its adoption.

In the context of media consumption, when three complementary devices are used simultaneously it is often referred to as the third-screen effect, a paradigm shift of the original living room dynamic of the user and his television screen (Tanakinjal, Deans \& Gray, 2010). The third-screen effect assumes that a participant is likely to be using a television, localized Internet-enabled device (i.e., laptop), and a mobile tablet or smartphone all at the same time or in succession (Tanakinjal, et al., 2010). The acceptance of tablets as a new substitutive or complementary device is a conscious decision on the part of the user, which has the potential to augment his platform selection preferences for future media consumption habits (LaRose, 2010). The decision is ultimately based on the relative platform benefits offered by tablets compared to existing devices, and eventually could affect the number of preferred screens a user consumes simultaneously. As tablet sales and tablet video usage continue to rise, the emerging platform is demonstrating that it potentially could supplant smartphones or PCs through either substitutability or complementarity. The impact of such a shift would not be limited to the adoption rate of tablets, but would also significantly alter the composition of multiplatform media use.

Accordingly, the following research questions are posited:

- How do users utilize tablets to consume media content traditionally available on television, radio, newspaper, and magazine platforms?

- What are users' perceptions of tablets as a media content platform in terms of benefits/needs met, accessibility, compatibility with existing media, usefulness, ease of use, and fun?

- How does a tablet substitute and/or complement its user's traditional media usage?

- What adoption factors are important for users to adopt the tablet platform for mobile media consumption? 


\section{Methods}

This study adopts the qualitative research method of semi-structured selfcompletion diaries. The decision to have the participants speak for themselves was a calculated selection to bridge the aforementioned theoretical framework with a methodology that could accurately assess their perceptions and experiences, despite its non-metric nature. It is also important to explore the user's interaction with an emerging platform in the most natural setting. To this end, an ethnographic approach seems most appropriate; however, historically, a media ethnography would depend heavily on the researcher as a participant observer, attempting to capture significance from the actions of participants without interference (Burgess, 2009; Feeley \& de Turck, 1995; Santhanam, Seligman \& Kang, 2007). While this methodology has led to significant studies on behavior (Feeley \& de Turck, 1995), IT training (Santhanam, et al., 2007), and education (Burgess, 2009), it is limited in its ability to capture the latent decision-making processes participants go through as they interact with new media devices. On the other hand, Corti (1993) suggested that "diaries" as a data collection instrument are useful in gathering contextualized, detailed, and sequential information about one's daily behavior and experiences, while minimizing problems associated with retrospective recalls. Sociologists have argued that "diaries" can be more accurate in constructing pictures of reality from the actors' perspective, delivering insight into the ways in which individuals perceive and interpret situations, offering a good alternative to research field notes in ethnographic research, and providing access to naturally occurring sequences of activity that might otherwise be inaccessible to participant observation (Bloor \& Wood, 2006; Corti, 1993; Plummer, 1983). This study utilizes the format of self-recorded video diaries instead of traditional written diaries. Contemporary developments in digital video, compression software, and high-speed Internet services enabled participants to use computer-mediated-communications (CMC) to record, compress, and upload their own thoughts on media consumption without the involvement of a participantobserver (Latour, 2005; Paccagnella, 1997). In addition, video recordings of the subjects themselves are likely to capture the thoughts, feelings, and experiences of their tablet usage more fluidly, as they have to use the tablet to create a self-recording. Finally, the video diaries used a semi-structured 
methodology to ensure the videos reported on key daily and weekly activities, experiences, and feelings related to the specific themes and uses of tablet devices for media consumption. The semi-structured approach avoids the restrictive detailed logs that might limit the subjects' free-flow of thoughts, but allows for a specified schema within which the diarists may state the events in their own words and expand on them (Lewis-Beck, Bryman, \& Liao, 2004). In the context of this study, the participants were presented with a list of daily tablet activities to check off and a list of suggested questions to address in the video diary. The questions included their overall feelings, thoughts, and impressions on using tablets to consume each of the identified media types; perceived changes in consumption behavior; and comparison of different platform experiences.

\section{Research Process and Instrument}

While random sampling provides the best opportunity to generalize the results of a study to the population of interest, it is not the most effective way to develop an understanding of complex issues pertaining to human behavior (Marshall, 1996). Best practices in qualitative research acknowledge that not all people are equally good at observing, understanding, and conveying their own behavior, and therefore certain informants may have superior capabilities at providing researchers with richer insights for analysis (Marshall, 1996). Accordingly, participants were selected using a combination of purposeful and volunteer sampling. Specifically, four subjects: two females and two males who were observed to possess typical communications skills, have experience in using various media devices, and could fulfill the two-week time commitment to participate in the study, were recruited from the undergraduate population of a southeastern university. Details of the subjects' media consumption/ownership profiles were examined to provide a better context for the subsequent video diary analysis; however, they are not presented here because of space limitations. It is worth noting that the participants personally owned different amounts of media devices; some were heavier media consumers of certain types of media than others (e. g., some participants consumed more video, while others read more magazines and newspapers); and there were differing degrees of technical inclination and innovativeness. A technology training session was 
carried out with the participants to ensure they were comfortable with all aspects of the tablet's usage.

As Apple iPads were the leading tablet model in the market at the time of this study, four iPad minis were provided to the selected participants. Each participant was instructed to use the iPad as much or as little as they chose to during their daily activities. At the conclusion of each day, pursuant to the aforementioned semi-structured list of questions, the participants recorded a video on the iPad that addressed their latent thoughts, feelings, and experiences using the device. At the conclusion of each week, each participant recorded a video that addressed their cumulative experience over the course of the week, how their thoughts regarding the iPad had or had not changed since beginning the study and, ultimately, if any of their media consumption habits had changed as a result of having access to an iPad. As noted earlier, each participant was provided with a media diary that suggested questions that would guide their video responses towards observations that would help to answer the proposed research questions. The suggested questions were a tool to aid in generating a more meaningful video, and participants were not limited to the questions proposed in the media diary. In terms of the iPad's functionality, in addition to the factory installed applications, each iPad was pre-installed with top-rated media apps such as Netflix, Hulu, Amazon Video, Crackle, You Tube, PBS, NPR, Pandora, Spotify, Rhapsody, Kindle, ABC Player, CBS Connects, CNN, Watch ESPN, Fox Now, Fox News, NBC, Podcasts, The Onion, Huff Post, Digg, and iReddit. The purpose of installing these apps was to have specific apps that correlated to the usage of video, audio, reading, news, and social media. At the conclusion of the two-week field study, 56 videos (14 per participant) were archived and transcribed for analysis.

\section{Results}

\section{Tablet Usage of Media Content}

The first research question addresses the users' tablet experience in consuming media content generally available on traditional media platforms (e. g., content found on television). Among all media types, video content 
seems to transition best onto the tablet format. All participants indicated having positive experiences consuming video on the iPad, attributing them to the high resolution of the display, the portability of the device, and the speed of launching a video. One participant stated, "The swiftness that goes into me pressing a button and hitting the Netflix app button and I'm there. I'm already watching. I don't have to turn on the TV or the Xbox. Whenever I want to watch something, it's there immediately." In other words, there seems to be an excellent perceived fit between the video consumption task and the tablet platform. Participant feedback on audio/music consumption via tablets was more of a mix. While they felt the tablet provides a more convenient means of accessing music than a computer for at-home music consumption, they did not think it offers the portability of a smartphone or other portable music devices like iPods for out-of-home usage. One participant noted, "I like my iPod better for running or exercising, because it's smaller and I can take it around. But I like the iPad better than the laptop for music, just when I'm around the house." They did enjoy the touch screen and app functionalities for music organization and navigation. Nevertheless, as an audio/music alternative platform, the tablet technology does not seem to capture the essence of the task at hand.

The participants also described the tablet reading experience positively, most often attributing enjoyment to the ease of reading text as a result of the retina display screen and touch screen functionality like copy, paste, zoom, and search. One subject stated, “Text is great and crisp, I love being able to zoom in on text fields and select them.” In general, the reflections toward the reading experience centered on e-book reading. Not much differentiation was made between newspaper and magazine content, as the subjects seemed to disregard the sources/original platforms of the content they read, but grouped the content as either text/image or video-oriented.

Relevant to newspaper content consumption, specific questions were posed about news consumption on tablets. The participants reported divergent experiences toward the news content on tablets, dependent largely on personal preferences in news type and consumption frequency. Very often news consumption is linked to the participants' social media use. One sub- 
ject stated, "The only news I seem to have looked at was probably through Facebook." One similarity appeared to be that none of the participants found news consumption to be their dominant use of the tablet. It seems the participants, who are not typically heavy news consumers, tended to use the tablets more as a platform for entertainment-oriented media content.

It is important to note that the use of the tablet as a social networking device was widespread among all participants. The fluid interface and information delivery, including the notification bar, immediacy of access to apps, and inter-app functionality were cited as reasons why the tablet was successful for social networking purposes. One subject stated, "I'm pretty much loving using these [social media] apps because of the notification bar. Even when I'm in class, I don't necessarily have to check 'Oh what's on Facebook, what's on Twitter,' because it comes down and it's quiet and I'll be able to see and still pay attention. It helps me multi-task." Despite differing psychographic profiles in respect to consumer innovativeness and social media usage, each participant did download and use or attempt to use the Facebook app on their tablet. This supports the findings of previous studies that identify Facebook as the dominant social media platform on mobile devices (Adobe, 2012). Facebook was not one of the preinstalled apps provided to participants.

\section{Perceptions of Tablets: Benefits/Needs, Usefulness, and Ease of Use}

As for the user perceptions of tablets as a media content platform in terms of benefits/needs met, usefulness, and ease of use, the participants consistently reflected on the tablet's ability to deliver immediacy and visual enjoyment. Specifically, the device's portability, convenience, virtual storage, high quality visuals, and spontaneous usage gratification were cited frequently as the benefits of using tablets for media content. One participant stated, "It's very convenient, clear, and portable." Another noted, "The advantage of the iPad is its very quick, up- to-date Internet instant gratification speed." Interestingly, the overall practicality of the tablet can be contextually dependent on the participants' micro-assessment of the device's usefulness. While some 
participants found the tablet to be a productive, useful tool, others admitted that it might be a distraction. One participant stated, “... I think it has increased my productivity a little, because I can do my work anywhere that I go if I bring my iPad... It's a little bit of a distraction too, because if I do bring it with me, I can just play Fruit Ninja or something like that." In other words, in the context of media content consumption, the participants considered the tablet to be very useful. However, in the context of all the functions provided by the tablet, some found the seamless integration and access to media content to be a distraction for the task at hand. In terms of ease of use, all the participants identified the device as simple to use. "The screen size, screen quality, touch screen, and interface are all really good. Very clear, very high quality. It's easy to use," noted one subject. In summary, the participants repeatedly stated the tablet's ease of use and quality of display were enjoyable when they consumed media content via this device. The factor of usefulness, on the other hand, might be more dependent on the specific task or objective the participant had in mind when using the tablet.

\section{Perceptions of Tablets: Accessibility, Compatibility, and Fun}

As the tablet is a converged media device, it has the potential to give users access to a plethora of media content that they may not have previously had access to. Participants appeared to have explored a diverse selection of niche and mainstream media content when given the chance to use a tablet. They felt there is a tremendous amount of accessible media content right at their fingertips, which is easy to access via the app structure. One participant noted, "It's much better than a book. You can find everything that you want." The accessibility to a multitude of content was noted in most of the diaries.

Much like the issue of usefulness (productivity vs. distraction), the participants differed in their views on the compatibility of the tablet to their daily activities. While some acknowledged the tablet presents a positive platform that is compatible with their daily media activities, others felt it did not really integrate into their regular media consumption.

Fun is an intangible latent positive association that can emerge from engaging with new technology, and has surfaced on several occasions du- 
ring this study as a way of describing a positive tablet experience. Despite the aforementioned disparities on usefulness and compatibility, all the participants agreed the tablet was a "fun" technology that is playful and enjoyable. Some illustrative statements include, "The iPad is fun in some senses. You can browse the Internet. You can look at videos," and "I got the most [sic] use out of the iPad than ever before. This lends itself mostly to the fact that I downloaded a ton of apps. They were fun." The intrinsic enjoyment of using the tablet was noted frequently in the video diaries and seemed to characterize the core tablet experience of the participants.

\section{Tablet Substitutability and Complementarity}

While the participants seemed to enjoy the various aspects of tablets as a media content platform, they were subsequently asked to consider how might the tablet substitute and/or complement their traditional media usage, and what might be the perceived relative advantages and disadvantages. Note that, since the participants only used the tablets for two weeks, the results here reflect perceived and emerging behavioral changes. The diaries indicated the participants had used the tablets in a complementary role, especially as a second screen; they were happy with the performance of the tablet in enhancing the consumption experience, citing the tablet's advantages as portability, visual quality, immediacy, fluid integration/interface, and app accessibility. Interestingly, when reflecting on the tablet's substitutive or complementary role, the participants tended to discuss the tablet in a substitutive capacity. In this context, the participants became much more specific in their expectations of the functionality of tablets. Some comparative statements include: 1) "I like my iPod better for running or exercising, because it's smaller and I can take it around. But I like the iPad better than the laptop for music, just when I'm around the house;" 2) “It's better than reading on a laptop, because it's basically like a piece of paper;" 3) “I think I've been watching fewer videos on my smartphone because [iPad] is just a better alternative for a quick glance at different movies or shows or even YouTube videos." In regards to music, one subject noted, "Without the portability [of an iPod], I wouldn't listen to audio on [iPad], because there's nothing special about it." From the perspective of social media, the integration, interface, and fluidity of the tablet was highly valued by all the 
participants, who are heavy social media users. One participant noted, "I downloaded Twitter and Facebook and I'm really enjoying it. It's just a really good experience in comparison to my phone, because sometimes I struggle trying to get to the next page [on my phone]."

The analysis of the diaries revealed that, at the initial stages of tablet adoption, the perceived complementarity and substitutability between tablets and other traditional media platforms depends on the type of media content. While tablets seemed to be used at ease by the participants to complement their video viewing, the devices were also a dominant substitute for laptops when consuming online television content. On the other hand, tablets as a platform for reading were seen as far more substitutive than complementary by the participants. Note that all participants, despite varying degrees of affinity for the tablet, acknowledged that having access to a tablet has increased their entertainment video consumption. One subject stated, "I'm not really too much of a video person, since I don't have time to necessarily watch a video or like TV and everything, but now that I have it in my hands, I kind of want to watch a little bit more, just because it's right here in the palm of my hands. It does kind of encourage me just a tad."

\section{Tablet Adoption Factors}

What factors might be important for users to consider using the tablet platform for media content consumption? The video diaries, as well as a contextual analysis of the participants' media ownership and consumption backgrounds, revealed the subjects who were more experienced consuming streaming media and are more innovative tended to prioritize immediacy and convenience as key benefits of the platform. However, they were also more critical when comparing the tablet to a PC in terms of functionality and cost-value. In addition, these participants were not as inclined to see tablets as a substitute for laptops in media content consumption. On the other hand, the participants who did not consider themselves technically inclined, emphasized the importance of visual quality, aesthetics, and ease of use. Finally, the participants who have already owned an array of media devices seemed to be more inclined to value the tablet as a media platform. 
In essence, the video diaries showed the participants enjoyed the tablet's technical qualities that enhanced their content consumption experiences, the fluidity of the interface and its integrated functionality, the fun and access to content provided by the app infrastructure, and the immediacy/portability. All the subjects agreed the ownership of a tablet would improve their media consumption experiences. Nevertheless, the willingness to pay for a tablet seemed to be influenced by the degree to which these values can be reasonably offset by the existing devices the participants already owned, as well as the tablet's affordability.

\section{Conclusions and Discussion}

This exploratory study utilized the self-taped video diary method to assess actual tablet users' media content consumption experiences. The results show all the participants had positive video viewing experiences, supporting the claim that tablets are well designed for the consumption of video entertainment content (Adobe, 2012). From the perspective of music/audio content, the participants seemed to indicate their needs might be better fulfilled by other smaller portable devices. On the other hand, the positive reading experiences described by the participants further expand the substitutive nature of the tablet for text/image content consumption. Nevertheless, news appeared to be not as highly coveted a use by the college level tablet users. It is plausible that the interest level might be affected by the typical lower rate of news consumption among younger media consumers (citation withheld for blind review). The findings here generally support the notions presented in the TTF framework, as the participants consistently evaluated their satisfaction of the tablet as a media platform dependent on how the device best delivered (i. e., fit) their media content. This is especially evident in the case of video content, where the retina display of the device resulted in high perceived fit for video consumption.

In addition to the receptive attitude toward traditional media content, the wide acceptance of the tablet as a social media device was to be expected as a result of its creation having been conceptualized post-web 2.0; therefore, it was able to address many of the ergonomic deficiencies found in pre-web 2.0 mobile technologies. Palm Pilots, laptops, and Blackbe- 
rries all released their original devices prior to the launch of Facebook in 2004, and it appears the web 2.0 phenomena is not limited to the UGC we see online, but can be found in consumer products being manufactured to help us specifically digest this content with great ease. Considering the enormous volume of information available on social networking sites such as Facebook and Twitter, in addition to the expedience with which new information is being posted, it should not be surprising that devices like tablets, which have the visual quality and easy interface to accommodate such content, are flourishing. Furthermore, the downloading and installation of Facebook by all the participants implies that consumers are beginning to establish a benchmark list of uses and expectations for their converged media devices, and designers and manufacturers should be wary of launching a device that does not meet such parameters. In an attempt to stay ahead of the curve in regards to desirable tablet functionality, future research should not be limited to just identifying popular benchmark uses; it also must flag out what tasks are being attempted on a tablet and are not being completed successfully. This would give manufacturers a window onto what functionality should be included in future devices. The integration of functionality is likely to affect the market potential of tablets as media devices.

Overall, the tablet's portability, convenience, visual quality, interface/function fluidity, and immediacy/speed are highly valued by the participants, as they reflected that most tablet experiences were enjoyable and fun. The positive comments participants had regarding the ease of use are a testament to the ergonomically friendly design of post-web 2.0 tablet hardware and software. The success of Facebook, Twitter, and other social networks was a result of their departure away from HTML and other coding languages and towards user-friendly content-management systems; such a strategy is being mimicked by tablet developers. The aforementioned social networks not only connect people; they also give the non-technologically savvy a way to engage, produce, and share content on the Internet. Similarly, the tablet has taken away the learning curve traditionally required by laptops and desktops. Considering many of the users of tablets are mature adults as opposed to students and teens, the growing adoption rate of the tablet might be highly attributed to its perceived ease of use. It would be 
interesting to investigate empirically the role of consumer innovativeness in the adoption of the tablet for media consumption, as it is a unique technological device that is perceived as a lower tech product characterized by user friendliness and an enhancement of existing innovations instead of generating new ones (i. e., tablets similar technologically to smartphones). In addition, while the factors of ease of use and accessibility seem to underscore the attractiveness of tablets, the notions of usefulness and compatibility appear to be contextually dependent on the user's latent preferences. As a converged media device, perhaps it is natural to focus the platform on usability and accessibility, but offer points of differentiation through functionality and compatibility. Note that, according to the findings of this study, fun continues to be an important factor in the adoption of technologically converged products. Further research might also be conducted specifically on the micro characteristics of fun to perhaps qualitatively or quantitatively evaluate what contributes to this latent consumer purchase motivator.

While the participants all complemented their existing media consumption activities with tablet usage, some also attempted to substitute the tablet for a few media platforms with varying degrees of outcome. The diaries, in general, characterized the level of substitutability to be in the form of a continuum with video and books (highly-substitutable) on one end, newspapers/magazines in the middle, and audio/music on the other end (limitedsubstitutability). The degree of substitutability linking these sets of media platforms has significant implications for the content production and marketing strategies of media conglomerates. It is important to note that the participants also frequently discussed the substitutability involving tablets, laptops and smartphones. It seems that tablets might be replacing laptops as the consumption platform for longer form videos, while smartphones are preferred over laptops and tablets for shorter form videos. Thus, it is possible that tablets might replace/substitute laptops and/or smartphones as the second/third screen, thus complementing video consumption in a multi-screen environment (TV, plus tablets). This observation is consistent with the "connected viewer" notion suggested by the Pew Research Center (Smith \& Boyles, 2012) and has significant implications for the social TV strategy of media firms. 
The growing ubiquitous nature of the tablet, coupled with the perceived visual quality and immediate gratification, provides an ideal infrastructure to support widespread mass media content. As the traditional broadcasters continue to increase their audience engagement via the tablet platform through various social media apps, it is important to see this platform as not only a tool for content involvement, but also as a means of content delivery. We are seeing the emergence of static Internet streaming set-top boxes such as Roku and Slingbox, but what if the functionality of a Roku was successfully embedded within a tablet? Such a strategy would capitalize on the HD quality display of the tablet and the increased video consumption addressed in the findings; as having your broadcast TV with you at all times can result in an initial increase in casual viewing that strong content can exploit to forge lasting relationships with viewers. It also would be wise for content distributors to provide users with tablet supported formats and dimensions, as they could potentially increase their market share beyond traditional mediums.

This study is exploratory by nature, thus presenting an array of limitations. The two-week field study might be too short of a period to assess more definite perceptual or behavioral changes. An application of the methodology used in this study across a longer period of time would assess the sustainability factor discussed in the aforementioned findings, by testing if they remain consistent over the product life cycle. Because the subjects did not own the tablets used in the field, they might be less likely to be engaged with the device in a substitutive role for their current media consumption. In addition, the participants were college students; therefore, there may be certain media consumption tendencies that do not lend themselves to tablet usage by students (e. g., news consumption). It would be beneficial to re-create and expand such field studies among the older age segments.

Despite the aforementioned limitations, the converged functionality (i. e., video recording, mobile uploads, $\mathrm{HD}$ video) of devices like the tablet now enables researchers to integrate computer mediated communications more organically into studies interested in assessing latent non-metric characteristics. While speaking for themselves and free of participant-observer 
interaction, the participants of this study confirmed the regular consumption of remediated video, audio, and social media content on tablet devices, citing claims of ease of use, fun, and unique functionality as the reasons for adoption. This further segments audiences across multiple platforms and supports the claim that the tablet can potentially compete with traditional entertainment consumption peripherals in a substitutive way. While this affirmation may represent a challenge to traditional broadcasters and publishers concerned with inter-platform competition, the immediate remediation of their content onto a relatively new platform demonstrates an opportunity for enterprise for those willing to accept the tablet as an entertainment device.

\section{References}

Ballve, M. (2012). US Adults Acquiring Tablets at a Dizzying Rate. Business Insider. Retrieved January 17, 2014 from http: / www.businessinsider.com/chart-of-the-day-tablet-penetration-2012-12.

Batsell, J. (2012). Intrigued, But Not Immersed - Millennial Students Analyze News Apps During the iPad's First Year. Electronic News, 6(3), 111-130.

Bloor, M., \& Wood, F. (2006). Keywords in Qualitative Methods: A Vocabulary of Research Concepts. Thousand Oaks, CA: Sage Publications.

Burgess, M. L. (2009). Using WebCT as a Supplemental Tool to Enhance Critical Thinking and Engagement among Developmental Reading Students. Journal of College Reading and Learning, 39(2), 9-33.

Corti,L. (1993). Using Diaries in Social Research. University of Surrey. Retrieved January 17, 2014 from http://sru.soc.surrey.ac.uk/SRU2.html.

Davis, F. D. (1989). Perceived Usefulness, Perceived Ease of Use, and User Acceptance of Information Technology. MIS Quarterly, 13(3), 319-340. 
Feeley, T. H. \& de Turck, M. A. (1995). Global Cue Usage in Behavior Lie Detection. Communication Quarterly, 43(4), 420-420.

Goodhue, D. L. \& Thompson, R. L. (1995). Task-technology Fit and Individual Performance. MIS Quarterly 19 (2), 213-236.

Ha, L., \& Ganahl, R. (2004). Webcasting Business Models of Clicks-andBricks and Pure-Play Media: A Comparative Study of Learning Webcasters in South Korea and the United States. The International Journal on Media Management, 6(1\&2), 74-87.

Igbaria, M. \& Liravi, J. (1995). The Effect of Self-Efficacy on Computer Usage, OMEGA. International Journal of Management Science, 23(6), 587-605.

Katz, E., Blumler, J. G. \& Gurevitch, M. (1973). Uses and Gratifications Research. The Public Opinion Quarterly 4(37), 509-523.

Kim, Y. \&Sim, J. (2012). Acceptance-diffusion Strategies for Tablet-PCs: Focused on Acceptance Factors of Non-Users and Satisfaction Factors of Users. ETRI Journal, 34(2), 245,-255.

LaRose, R. (2010). The Problem of Media Habits. Communication Theory, 20, 194-122.

Latour, B. (2005). Reassembling the Social: An Introduction to Actor-NetworkTheory. London: Oxford University Press.

Lee, K., Euiho, S. \&Park, J.(2012). A Study on Determinant Factors to Purchase for Tablet PC and Smartphone by a Comparative Analysis. Pohang: Pohang University of Science and Technology.

Lewis-Beck, M. S., Bryman, A. E. \& Liao, T. F. (2004). The SAGE Encyclopedia of Social Science Research Methods. Thousand Oaks, CA: Sage Publications. 
Li, A. (2013). Tablet Shipments Hit Record Levels While Apple’s Market Share Declines. Mashable. Retrieved January 17,2014 from http:// mashable.com/2013/01/31/tablet-shipments/.

Marshall, M. N. (1996). Sampling for Qualitative Research. Family Practice, 13(6), 522-525.

McGill, T., Klobas, J. \& Renzi, S. (2011). LMS Use and Instructor Performance: The Role of Task-technology Fit. International Journal on E-Learning, 10(1), 43-62.

McGill, T., \& Hobbs, V. J. (2008). How Students and Instructors Using a Virtual Learning Environment Perceive the Fit between Technology and Task. Journal of Computer Assisted Learning, 24(3), 191-202.

Moran, Mark J. (2006). College Student’s Acceptance of Tablet Personal Computers: A Modification of the Unified Theory of Acceptance and Use of Technology Model (Doctoral Dissertation). Capella University, Minneapolis, MN.

Murray, C. (2011). The Millennial Rumor: Understanding Millennial College Students' Characteristics, Digital Media Technology Usage, and Assumptions at the University of Denver (Doctoral Dissertation). University of Denver. Denver, CO.

Ozok, A. A., Benson, D., Chakraborty, J. \& Norcio, A. F. (2008). A Comparative Study between Tablet and Laptop PCs: User Satisfaction and Preferences. International Journal of Human-Computer Interaction, 24(3), 329-352.

Paccagnella, L. (1997). Getting the Seats of Your Pants Dirty: Strategies for Ethnographic Research on Virtual Communities. Journal of Computer Mediated Communication, 3(1), 0.

Palenchar, J. (2010). Analysts See iPad Success, Challenges. Twice 25(4), 1. 
Plummer, K. (1983). Documents of Life: An Introduction to the Problems and Literature of a Humanistic Method. Boston, MA: G. Allen \& Unwin.

Rainie, L. (2012). Networked Learners. Pew Research Center. Retrieved January 22, 2014 from http://pewinternet.org/Presentations/2012/ Aug/Networked-Learners.aspx.

Ruggiero, T. E. (2000).Uses and Gratifications Theory in the $21^{\text {st }}$ Century. Mass Communication and Society, 3, 3-37.

Santhanam, R., Seligman, L. \& Kang, D. (2007). Postimplementation Knowledge Transfer to Users and Information Technology Professionals. Journal of Management Information Systems, 24(1), 171-199.

Schramm, W. (1954). The Process and Effect of Mass Communication. Chicago IL: University of Illinois.

Singh, S. (2012). Smartphone vs. Tablet Adoption Trends. Tech-Thoughts. Retrieved march 17, 2014 from http://www.tech-thoughts.net/2012/12/ smartphone-vs-tablet-adoption-trends.html\#.UVdRX1d4_6k.

Smith, A., \& Boyles, J. L. (2012). The Rise of the Connect Viewer. Pew Research Center. Retrieved march 17,2014 from http://pewinternet. org/Reports/2012/Connected-viewers.aspx.

Staples, D.S. \& Seddon, P. (2004). Testing the Technology-to-performance Chain Model. Journal of Organizational and End User Computing, 16(4), 17-26.

Suki, N. M. (2011). Modeling Factors Influencing Early Adopters' Purchase Intention towards Online Music. International Journal of Technology and Human Interaction, 7(4), 46-61.

Tanakinjal, G. H., Deans, K. R. \& Gray, B. J. (2010).Third Screen Communication and the Adoption of Mobile Marketing: A Malaysia Perspective. International Journal of Marketing Studies, 2(1), 36-47. 
The Mobile Consumer: A Global Snapshot (2013). Nielsen Research. Retrieved from march 17,2014 http://www.slideshare.net/duckofdoom/mobile-consumerreport2013-17748641.

Zigurs, I. \& Buckland, B. K. (1998). A Theory of Task/Technology Fit and Group Support Systems Effectiveness. MIS Quarterly 22(3), 313334. 